needed to be addressed. This skillful work should be read by all those interested in French politics. Moreover, the book implicitly raises a crucial question, all too seldom asked: What do we mean when we say the word "socialism"?

William A. Pelz

Institute of Working Class History (Chicago)

\title{
Ralf Hoffrogge, Richard Müller: Der Mann binter der Novemberrevolution (Berlin: Karl Dietz Verlag, 2008).
}

Biography has long been a tool used by historians to highlight the nuances of societal change. Of course, this form suffers from the danger that a form of hero worship will lead the scholar into the pitfall of the "great person theory of history." Fortunately, this work avoids this problem while remaining sympathetic to the subject discussed. Hoffrogge has authored a brilliant biography of Richard Müller (1880 - 1943), German radical and author. Although now known only to professional historians, he and his comrades in the Berlín Revolutionary Shop Stewards were important leaders of mass strikes in the years 1916-1918 (9) and later in the events of the German Revolution. After a brief career as a radical workers' leader, Müller left politics and faded into the mists of historical amnesia. With this book, the mists have parted and Müller's significance is again revealed. In addition to his political activism, Müller authored a number of significant works of history such as Vom Kaiserreich zur Republik. (1924). Curiously, the importance of his written works has until now not spared him from historical obscurity.

When discussed at all, the November Revolution is often presented as an event without thought or planning. This does a great disservice to the many unsung radicals like Müller who had laid the groundwork for a workers' revolution. An independent thinker, he began politics in the German Social Democracy (SPD) and later moved into the German Communist Party (KPD). He was never a docile follower of either, opposing the SPD support for World War I and later refusing to join the KPD's early incarnation Spartaksubund because of his fear of ultra-left elements overly enamored with an armed seizure of power (97). Later, he would join the KPD with many of his former comrades only to be politically crushed within a few years by the vicious political infighting and meddling by the Comintern.

Within the Revolutionary Shop Stewards, Müller attempted to develop the strategy of initiating action as union representatives of industrial workers while clandestinely forming an illicit revolutionary organization in response to wartime repression. Although they were key players in the events of 1916-1919, this group has often been overlooked by scholars. Ralf Hoffrogge has authored 
an invaluable addition to the literature of German radicalism by detailing the life of one of the key leaders of the Revolutionary Shop Stewards. Müller and his comrades provide an interesting contrast to more well known supporters of Social Democracy and Communism within the German workers' movement. As the author suggests, Müller may have been the Sisyphus of the Revolution (221), but his was also a very real human story. This work fills an important gap by bringing to life an indigenous German radicalism that briefly, many might say all too briefly, played a vital role in revolutionary politics.

William A. Pelz, Institute of Working Class History (Chicago)

\section{Lewis H. Siegelbaum, ed., The Socialist Car: Automobility in the Eastern Bloc (Ithaca: Cornell University Press, 2011).}

The subject of automobility has developed quickly in American history, but its growth elsewhere has been slower. Given the lack of cars of any quality in the Soviet sphere, it should also not surprise us that it has taken so long for studies of automobility - the broad study of all aspects of social, political, and economic life that surrounds driving culture and the systems of which it is a part- to reach Eastern Europe. The Socialist Car is the broadest introduction to automobility in Eastern Europe, edited by the scholar who raised the issue in Soviet history.

This volume developed from a 2008 Berlin conference. Its eleven chapters are divided into three thematic sections: production, distribution, and consumption; urban planning; and a catch-all chapter on car cultures.

Three chapters deal with the ways in which automobiles intersect with political power in Czechoslovakia, Poland, and Hungary. Valentina Fava explores how the quest for a car for the people in Czechoslovakia failed to return to Bohemian technological success. The promises of socialist efficiency continued to pale in the face of nearby western engineering and marketing and left Ŝkoda without a widespread world market. Mariusz Jastrząb investigates vehicle distribution in Poland and finds that cars as favours in the socialist period developed from interwar behaviours. Jastrząb describes this authority of favours as personal rather than administrative. The reasons why the state distributed cars changed over time from, for example, clientele building to loyalty prizes for union activism as the regime grew increasingly unpopular in the 1980s. György Péteri explains how Hungary chose to ignore Nikita Khrushchev's car sharing. As the state apparatus used cars as a form of status and mobility, it catalyzed the movement for private ownership in the general population, often to the detriment of communal transport. The "convergence of socialism with capitalism" started in 